\title{
UNITY IN RESTORING: A STUDY ON HEALING ATTRIBUTES OF PERSIAN GARDEN
}

Reza Ramyar

\author{
Faculty of Landscape Architecture, Shahid Bheheshti \\ University, Iran \\ e-mail: reza.ramyar@gmail.com
}

\begin{abstract}
Spending time in a Persian garden gives one the impression of being away and a sense of connection with nature. These feelings alleviate mental fatigue, or stress and bring about mental restoration. Simply, one feels mentally refreshed after visiting and strolling in a Persian garden. The motivation for the research is to evaluate the theory that whether Persian traditional garden can be used as a restorative garden or even its design principles can be employed to create an environment of such kind. The main areas of investigation in this paper include understanding restorative attributes provided with the garden on visitors. Persian garden provides opportunities that intuitively engender restorative attributes which can fully be felt by being there, whether it was intended for such a purpose or not. The paper tries to imply that the aim of creation of such spaces (Persian garden) was so supreme that restoration can be considered as one of the subjects which arouses from a dominant interrelation between human and space (nature) in a common entire inherence.
\end{abstract}

Keyword: Persian garden, restorative garden, healing attributes, mentally refresh

\begin{abstract}
Abstrak
Menghabiskan waktu di taman Persia memberikan satu kesan terasing dari keramaian dan rasa keterhubungan dengan alam. Perasaan ini mampu meringankan kelelahan mental atau stres, dan membawa pemulihan mental. Secara sederhana, seseorang merasakan kesegaran mental setelah mengunjungi dan berjalan-jalan di sebuah taman Persia. Motivasi penelitian ini adalah untuk mengevaluasi teori bahwa apakah taman tradisional Persia dapat digunakan sebagai taman restoratif, atau bahkan apakah prinsip-prinsip desain taman tersebut dapat digunakan untuk menciptakan lingkungan semacam itu. Area utama penyelidikan dalam makalah ini meliputi memahami atribut restoratif yang disediakan oleh taman kepada pengunjung. Taman Persia menyediakan kesempatan bahwa atribut restoratif yang ditimbulkan secara intuitif yang dapat sepenuhnya dirasakan dengan berada di sana, baik hal itu dimaksudkan untuk tujuan semacam itu ataupun tidak. Makalah ini mencoba untuk menyiratkan bahwa tujuan dari penciptaan ruang tersebut (Persia kebun) begitu tinggi sehingga pemulihan dapat dianggap sebagai salah satu subjek yang bangkit dari keterkaitan utama antara manusia dan ruang (alam) dalam keseluruhan hal yang mendasar.
\end{abstract}

Kata kunci: Taman restoratif, taman Persia, atribut penyembuhan, kesegaran mental

\section{Introduction}

Public spaces, either outdoors or indoors, like gardens, squares, bazaars, bathes, stadiums, etc. not only response to some fundamental needs but also provide a public life for people. Governors and people seriously attend them with various motivations. People from different cultures in the light of their desires try to present them in their own spaces. Some of them incline to erect huge struc- tures which never have been seen, others incline to ornate the architecture and some try to create a paradise on the earth (the Persian garden is a sample of it). It can be seen that some attributes are emphasized in public open spaces versus personal spaces which people want to find them in public spaces, likewise; being away from routine life, having recreational environment, experiencing life among others, aesthetic pleasure and abilities, experimenting their ideals, which are the 
features mentioned in this paper. Also, generally they are considered in public spaces and particularly in restorative spaces. These kinds of common features, believing on the concept that timeless traditional spaces are a tree which can blossom in any situation by preservation and consideration were among the motivations of the paper.

The environment in this regard at first is a place for alleviating people's need and then a place for expressing such qualities which are based on their cultural and social desires of perfect seeker soul of human in all era. Gardens are spaces that can be seen in all traditional cultures. The Persian garden, in line with Iran's history, moved along its evolutionary path of changes, and was responsive to the demands of periods. During this process, the garden, or the concept of the Persian garden, has been utilized as a base in creating such spaces. The garden has been the place where many public 
activities occurred like playing games and music or even holding philosophical debates since the Safavid dynasty $^{1}$. Such activities also can be seen in Persian miniature paintings left from that era ${ }^{2}$. Hence, the garden was ingrained with people's private and social lives and was a framework for fulfilling people's needs concerning their relationship with each other and with nature in any outdoor space.

Restorative gardens have turned to be an interesting subject around the world. Though the subject of restorative gardens may seem be relatively new, actually it is not. According to Nancy Gerlach-Spriggs, "Restorative or healing gardens for the sick have been part of the landscape of healing since medieval times. A restorative garden is intended by its planners to evoke rhythms that energize the body, inform the spirit, and ultimately enhance the recuperative powers inherent in an infirm body or mind. Wherever recovery is not possible, intimate contact with the cycle and flow of nature may yet

calm the spirit"3,4.

The paper's approach to find the restorative attributes of Persian garden is describing relation- ships between the garden as an environment and restorativeness as an effect on human. In this regard firstly, it considers the human by the glass of environment and in the following it considers to the environment by the glass of human attitude. It means at first it will be narrated the affordance of environment and secondly it will be described the impression on human which is elaborated by his perception in the field of restorativeness.

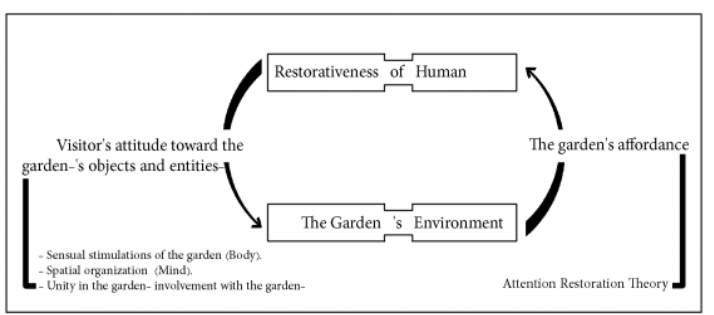

Figure 1. The paper's approach to find the restorative attributes of Persian garden

\section{The Garden's Affordance: Through the Attention Restoration Theory (ART)}

Since the early 1970s, two major interpretations of what constitute a 'restorative experience' have dominated the restorative research literature. They have also taken into consideration the effect of the environment on psycho-physiological well-being, which express against the background of Ulrich's stress reduction theory $\left(\mathrm{SRT}^{5}\right)$ and Kaplan and Kaplan's attention restoration theory $\left(A R T^{6,7}\right)$. According to SRT (Stress Recovery Theory), exposure to unthreatening nature or even viewing natural elements activates a positive affective response, a behavioral approach orientation, and sustained, relaxed attention and leads to more positively-toned emotional states. In Kaplan's attention restoration theory, $\mathrm{ART}^{7}$, it is declared that environments with particular characteristics may allow people to restore for directed attentional capacity. Such restorative environments should have four characteristics. All of them are dependent on an interaction between the place and the observer. Environments with elements of all four components promote the involuntary attention mode of information processing, and can lead to restorative experiences in which individuals may develop a state of cognitive clarity, enabling a pleasurable and contemplative state of mind $^{8}$. They are being away, extent, fascination, and compatibility.

\section{Being away}

Being away is the act of removing oneself from the set of circumstances that have become a usual pattern for some variable length of time and are depleting the capacity for directed attention ${ }^{6,9}$. They say, "People seeking a restorative experience speak of needing to 'get away' and may describe the desired experience as a 'change and a rest'. The necessary factor for being away is a change of what is going on in one's mind. Being away "involves a conceptual rather than a physical transformation."

Persian garden (Figure 2) by its all views inspires us to move, wonder, observe and develop our body and mind ${ }^{10}$. It provides adequate emotional stimulants and cognitive structure. It adds dimension of total acceptance and emergence in the "restorative experience".

Water's murmur along with other fascinating sounds fills the ears from a close distance. An alteration in the entrance and porous panels around the entrance hall, providing a vague image of the garden, all create a hierarchy of entrance for the viewer ${ }^{11}$. In fact the visitor is allowed to get inside in a step by step manner. Experiencing Persian garden gives one a sense of being away; a sense of connection with the nature. These feelings are accentuated by trees planted along the central axis. Geometric order and linear corridors bring in deep views creating a unique character for the garden. Tall plants and vegetation filtrate unwanted environmental noise. Experiencing one's surroundings in such a new way can bring in a sense of being away from one's usual set of circumstances.

\section{Extent}

Extent is described as the characteristic of a space or situation that makes one feel as if he or she is "in a whole different world," either physically or perceptually, ${ }^{6,9}$. While the concept of being away is the escape from one's usual set of circumstances, extent is the characteristic that engages one's mind 
in the surroundings. It can only be authentic if connection and scope are present ${ }^{6,9}$.

Defining a space as a garden itself has an influence on providing "extent" by its characters. Movement as a kind of action and fascinator in the garden, and emotions which are aroused by distraction of mind a while from life and its problems loose individuals from unduly notion and thought. Hence in such actions in the garden interconnections transform to interaction and interrelation between persons and spaces. In the linear paths extent of Cedars trees and such axistic trees display green extent for passengers. Running water (blue on the ground) and the sky which seen among tall trees (blue on top) engage the mind the way (Figure 2). The first property, interrelatedness, refers to the coherence and legibility that exists in the elements that are immediately perceived. With a sufficient level of coherence, one is able to recognize pieces

that compose a portion of some larger whole 6 . In

other words, one is able to identify an overall picture that is comprised of several different elements or features.

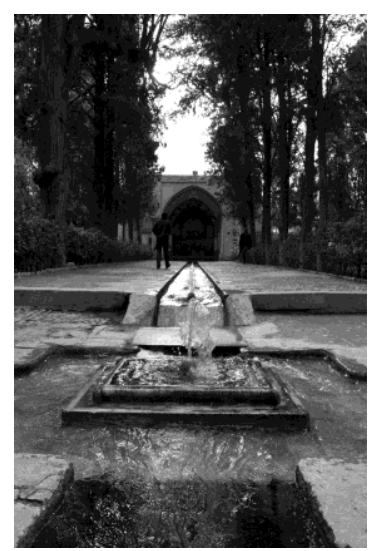

Figure 2. Persian garden (Shazdeh Mahan Garden, Iran, Kerman) in differentiation with its context [26]

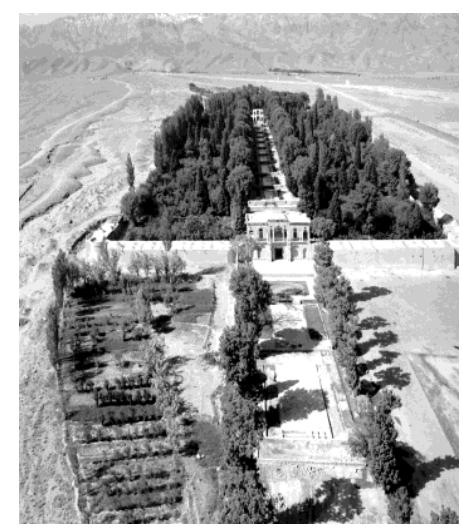

Figure 3. Persian garden (Fin Kashan Garden, Iran, Kashan), water as one of the main elements in Persian garden
Without a sense of connectedness among environmental features, the experience is merely an unrelated collection of impressions and may in fact cause confusion ${ }^{7}$. Legibility in the garden that will explained bellow by title of "spatial organization" is important spatially in that one is able to comprehend the overall physical environment, can begin to make predictions about other elements that exist or progression that may occur, and may anticipate and seek out these predictions. As Kaplans said, an environment that has an appropriate quantity of things to see, experience, and think about so as to substantially fill one's mind will have a sufficient level of scope ${ }^{12}$. It can be seen in changing of water feature during passing by squirts and cascades and so it has preference in their repetition and rhythm. It can be seen in the rhythm of garden's features and fascination order to its discoveries. Scope is the richness within the space that provides complexity and mystery ${ }^{6}$.

\section{Fascination}

Fascination can be described as the ability to create a curiosity. This curiosity causes an unintentional focusing of our attention on stimuli in the environment through interest and excitement. One point perspective which leads use to front to heart of the garden can be considered as a main fascinating factor in Persian garden (Figure 3). It act as an always target in the entire axes to be regarded, to be reached, during strolling in the garden. It emphasized by the form and height of trees and running water. The garden is full of fascination, trees, palace, other plants, water, and wildlife, never ceasing to intrigue and captivate the viewer. Running of water in contrary of passenger's movement is felt the water comes to cut through the innate with its beautiful sound and various tones in different places. It acts as fascinator for movement in inward, in thought.

\section{Compatibility}

Fascination can be engaged by environmental contents or by the process of activity. Compatibility refers to the congruence between opportunities and constraints afforded by the setting and a person's inclinations. Compatibility is the agreement between the demands of the environment and one's purposes and inclinations ${ }^{6,12}$. An invitation to stroll in the garden by its fascinations and an acceptance in return by the passenger makes the two to become one, experiencing a whole new kind of existence. Persian garden is a built nature in Persian context. All human aspects are considered in the garden with its holistic approach. During centuries its goal was to expresses a unity between man and garden (human/ nature). Persian garden brings about a new meaning to compatibility, apart from what may be expected. 
The concept is achieved by the spatial order in the garden. It affects through the ones needs to relate with nature; and it happens so unconsciously, using interrelations and correlations with such basic human needs.

\section{Visitor's Attitude toward the Garden's Objects and Entities}

The concept of restoration has several connotations, some quite concrete, others more spiritual and mental. Generally speaking, however, healing may be said to be a process that promotes overall well-being $^{12}$. So in the question of how the garden effect on addressee in the space, it must consider that how it effect on overall human layers; body, mind and soul. Visitor's attitude toward the garden's objects and entities is considered in the paper in three parts: sensual stimulation of Persian garden, spatial organization, and unity in the garden (involvement with the garden).

\section{Sensual stimulation of Persian garden}

The environment is perceived through the senses which act in unison to produce a sensation. The perception of the environment effects user's healthy by causing him or her to react to envi- ronment stimuli either in a positive or negative man- ner. The senses have the first exposure and reaction to an environment. Their role and relevance to health and nature is explained and related to an aes-

thetic experience. According to Tuan ${ }^{13}$, a pleasing landscape must impact our senses and provide us with a "shaped" feeling of what we are experiencing.

The perfect garden awakens the senses with natural pleasures that heal and refurbish the soul. An integrated representation of any physical environment combines various sensory modalities, the visual, tactile, olfactory, and kinaesthetic ${ }^{14}$. Sensual perception causes us to react and adapt to our environment. When a stimulus is experienced it is seen as a sing unique experience. However, that experience is really the result of several sensory inputs working in unison to make up that one experience. It is intended to identify and analyze the natural stimuli in Persian garden that is preferable

and sensually stimulating. This will lead to understand the satisfaction factor and well-being through a subtle interaction with garden elements through its sensual stimulations.

\section{Sight}

"Pleasure vision" is sensed comprehensively during the experience in Persian garden. Accurate scenario; start through entrance hall with opening holes in the walls and so garden's persuasions and instigations, behind the wall at the spark of entering spawn recalling our all the past mental images of 
gardens and nature ${ }^{11}$. Hence the first stroke of separation from body and memorability is impacted during the entering; in entrance hall sounds of the garden can be heard, an early turn and then a light comes inviting the visitor to a leading path. A path which is exactly coinciding with the garden's axis, providing a view of the palace and running water at the first glance. Now it's when the garden displays its beauty to instantly catch the visitor's mind.

'Pleasure vision' that is a delightful sightseeing can be discerned in order, rhythm, symmetry, hierarchy and perceptual balance. It accommodates variant views and aesthetics in different season ${ }^{11}$. Persian garden is an orchard garden. Fruits in it act as a goal. Our Four season garden imparts four season pleasure vision. Its spring is full of colors and flowers. Each compartments has its own character and colors and species. The pleasure vision peaks in spring. Berry, cherries, sloe, apple, almond, quince, and all of them flaunt in the garden. The visions not only have diversity in seasons but also in months or even in weeks. Mind is confused in this variation of colors and fragrances. Vegetations and trees blossom in different period hence bringing about new narratives from garden by every new day. The flowers are soon on the ground, and make a colorful carpet for the garden. Finally new fruits bring colors and flavors to the garden. Now summer could be seen in the garden; season of yield, bearing, heat and water. Red apple, red and yellow peach, green sole and berry with various color, bring the garden into life. Blood of oxygen and color is circulated in garden in this season. Blowing autumnal wind noticed inception cool season. Variant trees slowly and little by little fall; piecemeal fall carry various autumn days and colors. In sad autumn green trees and greenery in garden are sign of life in the garden and remind it to the users. Nowadays autumn fruits with their heart color rioted; orange, persimmon brings pleasure vision to the garden. In winter in sleep of nature, four season garden with evergreen trees and winter flowers such "Winter spice" so bring color to space, however less. In the poverty of nature, low beauty in the garden provokes intensive emotions. Another nature's plays and senses in another season. Cognition is enhanced by this "tactile vision" that enables us to visually touch and explore an object and categorize it as an experience

that is placed in our memory ${ }^{13}$.

\section{Smell}

Smell is of primary importance in the aesthetic experience. Sight and sound seem to objectively analyze a situation. Smell immediately refers it to a subjective, sensual feeling. The garden makes a subjective place in our mind also with its fragrance of flowers and plants in faraway awake others to (make

186 | Journal of Islamic Architecture Volume 1 Issue 4 December 2011 others known) presence of a garden by the way, 
invite passengers to stroll and proffer them a sense of pleasure out of garden ${ }^{11}$. Fragrance in Persian garden usually describes plants and other garden elements that stimulate the sense of smell and react in a positive manner. This reaction can cause satisfaction and sensual harmony in most individuals. It brings forth a spiritual message that touches all who come in contact with the garden. This garden through a mental, emotional, and physical interac- tion bring people closer to itself.

The Garden imparts its decency and beauty to people who pass next to the garden. Four seasons, forty weeks and fourteen day's garden gifts us fragrances of different species of flowers. Fruits and flowers were found to highly preferred fragrances when compared to scents of unnatural products. Because we are familiar with most aromas in nature we feel comfortable and familiar with them and refer to them for past remembrances. The impor- tance and attraction of fragrance in our lives is an innate response.

\section{Taste}

By including fragrant and edible plants, garden users can experience yet another level of sensory inspiration. One of the greatest joys of gardening is sending your taste buds into raptures over the flavor of 'real' fruit or vegetables ${ }^{15}$. We don't place too much emphasis on taste as an aesthetic experience. However, when it includes the act of eating it becomes a very potent and sensual event ${ }^{13}$. The fruit of our labor give us pride, self-esteem, and a feeling of accomplishment. According to Ackerman ${ }^{16}$, taste is a social sense. Because this brings people and nutrients together it is a sense that fosters emotional as well as physical health.

Their dropped fruit stains the garden and this is when small animals and birds come to find life in the orchard garden and man can enjoy a close reaching being with them. Plants with berries add a seasonal interest, attract birds and other wildlife, and supply tasty treats. Children also find them inspiring, their colors are usually bright and vivacious, and fun to pick and eat.

\section{Hear}

Paying special attention to plant selection can again attract a variety of insects and birds to your garden. Persian garden is always attended by birds. Garden, flower and nightingale forever are together, even in poem and writings in Persia. Emigrant birds in four season garden donate variation in sounds separate it from monotony. In deciduous autumn persimmon attract birds to garden. Oriole in summer is settled behind the walls. Different vegetations invite different birds into the garden, making each group of them singing their own song for the garden.
One of the prettiest sounds of natural world is chirping of birds ${ }^{11}$.

Persian garden uses trees and bushes that create pleasant sounds when coming in contact with the wind. The Aspen make a sea like sound when wind goes through its leaves and branches. That goes pleasant with the sound of pouring water on the rocks. Persian garden has continuous "live sound" all year long.

Water is a wonderful element to incorporate into the garden because of the different levels of sound that it can provide. Water as one of the main elements in Persian garden, intoning its being sound in some places and in other it dialogue, and on points shout and so cause our spirit ascend in sama ${ }^{17}$. The garden uses a foundation that causes water to be soft in appearance and sound. It uses a small pool as a reflective element in garden. Small cascades create a healing sound as the water softly falls against stones. Add sound by placing a water spout imprints its signature in the pool through currents of sound and movement. The garden conveys all the forms and feature and emotional inspiration of water.

\section{Touch}

Tactile stimulation is adventurous in nature. Touching an object to explore its meaning is an innate action that requires sensitivity and an absorbing mind. We literally have the ability to "feel" our world. By feeling the wind on out faces, the soil and grass in our hands, the warmth of the sun or the coolness of a northwest breeze on our skin we can experience nature as a receptive energy field. The tactile experience involves a degree of anticipation $^{18}$. Texture is a surface quality that is defined by an objective's appearance and feel. Tree barks are good tactile stimulators and offer a variety of colors and textures that are especially pleasing during the winter months.

The water feature symbolizes "The Cycle of Life". The different phases of life from birth to death are symbolized in various ways by means of quiet pools, as well as flowing streambeds. Ulrich ${ }^{5}$ considered the presence of water to be an indicator of an environment's high restorative potential. Throughout the site water is not only audible and visual but also touchable throughout the garden. The sound and touch of water, is completed by plants which reflected the changing season and also encourage wildlife.

\section{Spatial organization}

An important feature of the garden is that it should be possible to experience it as a whole, marked off from the surroundings. Through the ages the garden has been defined as a piece of enclosed ground $^{4}$. It is important how it is shaped, its well 
design, give the visitor a feeling of being away and of being safe. The importance of design and its relationship to health cannot be overlooked, since it is the impetus behind a successful aesthetic solution that contributes to wellbeing. They are one and the same as natural laws of health and harmony. Spatial perception is a sensual experience that is detected by the tangible qualities of a space, i.e. pattern, texture, and order ${ }^{19}$. Space is also perceived thorough to the interrelationships between its elements either together or in response to the surrounding space. The form and meaning of spaces in the garden is directly connected to its placement within a hierarchical organization of subspaces. Spaces create wellbeing when they are balanced in their arrangement with other spaces and their structures are endowed with the aesthetic characteristics that produce pleasure.

Legibility is the main factor in traditional gardens. An open space offers information about the environment and if it is legible and understandable a mental relaxation occurs ${ }^{6}$ and this comes to be very important for well-being. A sense of calmness and tranquility comes about when the complexity and

intensity of textures and patterns is at a lower level ${ }^{20}$. Stress is controlled by stable, legible and predictable movement. In Persian garden forms and arrangement of trees and the running water as well as pools and stable water are so related together and also to other elements. Such an organization which makes a garden as it is seen is balanced in complexity and intensity. That should be planned so that they look softer in quality. These appearances may illicit feelings of well-being. Using such symbols in Persian garden, a space is created that is used for restoration and spiritual reaffirmation. It can help us

experience a space that awakens the subconscious for a healing that is personal, effective and integrative of body, mind, and spirit.

\section{Order}

Order is the arrangement of forms that brings equilibrium to the organization of space. The structure of a space is defined by its organizing patterns that control its function, its progression, and its aesthetic appearance. Since order is a principle of spatial organization, balance, unity, and rhythm may be seen as aspects of order when used within this context. Balance is the most important psychological as well as physical influence on human perception. Equilibrium is our firmest and strongest visual reference, both the conscious and unconscious basis

for making judgments ${ }^{21}$. Balance brings a perception of wholeness or completeness. The concept of balance is an important consideration in a Persian garden (Figure 4). It strengthens and integrates the elements of color, form, texture, and scale into a healing design. Strong edges and 188 Journal of Islamic Architecture Volume 1 Issue 4 December 2011 repetition of these 
through the Persian garden, gives the garden organization, legibility, and aesthetic order. It is built through a geometric order. Elements in a geometrical arrangement form the garden spaces. Geometry can be seen in all the artifacts in the garden.

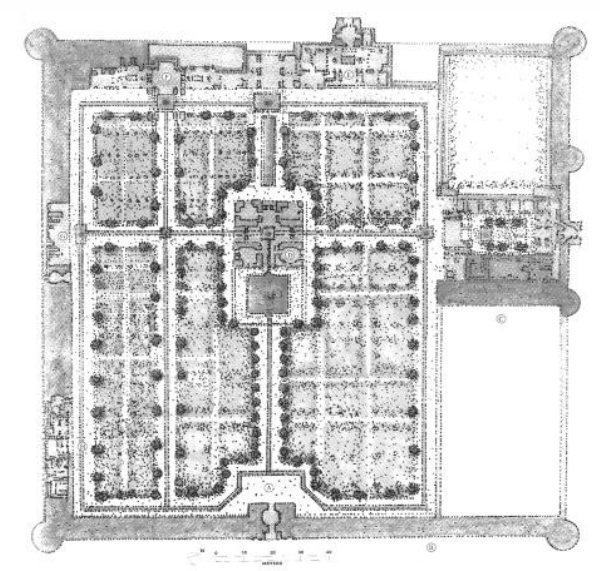

Figure 4. Persian garden (Fin Kashan Garden, Iran, Kashan), order and circulation pattern can be seen in this plan [2]

A classical or symmetrical order in Persian garden divides the space along an axis or around a center point and arranges the garden forms in a mirrored order. This offers the user a very ordered, structured, and balanced appearance that makes a universal harmony which happens to be important for the health too. It makes one feel as though a higher power has brought life into an order and a balanced existence.Linear path imposes order and a visual focus on the garden organization. This strengthens the visual perception by placing the space within boundaries. Persian garden frames the space through vertical elements; which are trees and corner walls (Figure 3). There is a focal point in every Persian garden that addresses healing, such as the "focus of tranquility", which is placed at the center and it becomes less forceful by the elements located around. It provides an orderly and strong placement of spaces and defines their places and values through hierarchy, repetition, pattern, and rhythm. In the garden the pavilion acts as a land mark. It has been suggested that visual landmarks facilitate orientation and therefore provide a sense

of ease and rest ${ }^{9}$.

\section{Circulation pattern}

The garden is created with a circulation pattern that functions with the space and defines a legible pattern of movement. According to Lynch, this causes a feeling of relaxation ${ }^{22}$. Paths define the circulation pattern and so circulation defines garden's pattern. Persian garden has a movement inside itself. Circulation and the arrangement of paths form the geometry of garden. All the elements are placed 
and formed in the light of what the paths define for the garden. Pleasantness of the garden is derived from its appearance; rhythm, symmetry, and ba- lance, and they are seen in paths. So it can be said that unity in the garden, is shaped on a physical arrangement basis. The entry of Persian garden is an important design consideration in its arrangement. It is the first step in the way to be encountered by the garden. It is strong, well organized and ornamented and inviting so it attracts individuals to experience what the garden has to offer (Figure 5). According to Cox, two or three different forms are all that is needed to keep a garden aesthetically pleading and relaxing ${ }^{23}$.

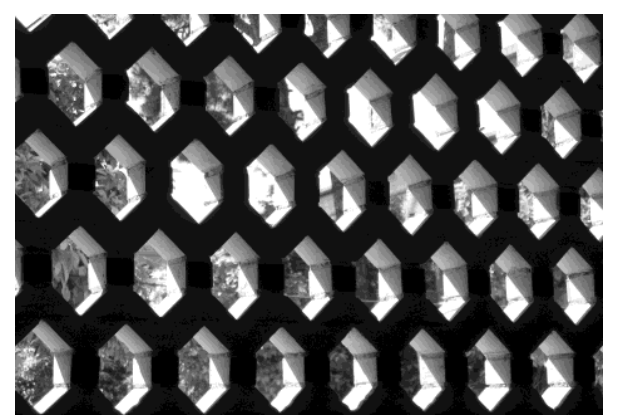

Figure 5. Latticed surface in the entrance hall helps to see the garden before entering there

Unity in the garden: involvement with the garden

Earle describe unity as the "spirit of the de- sign"24. Unity in the space defines the space as wholeness. Perception of unity in space arrangement is understandable and presentable. 'Unity or the production of a whole is a leading principle of the highest importance, in every art of taste or design, without which no satisfactory result can be real-ized'25. We need unity to feel the whole ${ }^{19}$. It is naturally understood that as a motivating principle unity carries us forward in our perception of environ- ment. It shows a sense of harmony or wholeness that is part of the human. 'For the best organization, the parts should be organized so that the whole is seen before the parts $^{21}$.

What we introduce in the unity of the garden is not only emotional or mental aspects but also is a base affected by them but created an experience, the one in another world, and the world of garden. According to R.H Robinson, experience rather than space in design causes the observer to accept or reject the space ${ }^{19}$. The environment of the garden as a whole space with space alternation and sequence and mental and emotional stimulants create environmental experience, and, according to Cornell, physical healing and spiritual transformation can occur $^{26}$. It is in this layer that the world of the garden is felt by accomplishment of spatial experience. The focal essence of space is presented. We may sometimes get involved in games in the garden, so

190 | Journal of Islamic Architecture Volume 1 Issue 4 December 2011 that we may forget our position in the world and enter the garden's world since the garden itself is a complete world ${ }^{10}$. The garden pulls us into its spaceworld by its internal and external fascinations. Seeking the garden equates with seeking the self, when the garden is experienced to its fullest. All signs and stimulants unify to be perceived as one, and finally turn into one quality: unity of spatial experience.

Such an experience makes some kind of movement and florescence inside us. This experience is resulted by interaction of space (with all its features as a complete world) and person (with all his states, a world). In this experience, the spacegarden provides us an understanding of the subjective and objective worlds simultaneously. The space gets to flow and be understood in the mind and gets internalized forever. This is how one senses a unique feeling and perception in the face of the disappearing space.

To describe this kind of unity in the space more concretely, we take advantage of language. If we consider space as a language ${ }^{27}$, and consider the garden or any other special space as a statement, the feeling of reading it will be equal to experiencing space. Some are superficial, while others are mind-boggling, appetizing and astonishing. There are some that make you modest. "Unity of spatial experience" in the garden's world can be expressed as a statement that seems to carry otherworldly scents. It is arousing and nurtures the experiencing person. It becomes exciting like a beautiful poem or verse. This excitement is neither from prosodic principles (spatial arrangement) in poems, nor from the nice words (emotional stimulant) that are used alone or in different contexts. It rather seems to unveil a world before our eyes in this special situation. So, it looks like as an internal creation: the composer has placed something from inside him into the masterpiece that interacts so effectively with the one who observes it.

Unity of spatial experience is a sort of experience that cannot be expressed in words. It has to be experienced as it is. It sounds useless to talk about it. Space, context, ideology, knowledge, and religion have all come together to make a creature in the form of the garden. Persian garden presents life's natural rhythm in the form of a unity of the body, mind, and spirit that causes full restoration.

\section{Conclusion}

Traditional gardens, all those born in a particular culture, have come to existence by the people in that vicinity based on their comprehension of an organized space and their tendency toward a particular way of forming it. Their built spaces all crystallize from an initial mentality forming them. 
The thing that keeps these organized spaces alive during the times is their inborn bond to the human and his unconscious.

Though it is clear that these spaces thrill the people from where they originally come from, but they also come out to be a pleasurable and remedial place for the strangers as well. On describing this ample effect with all the characteristics discussed earlier in this paper, the matter is being presented with no regards to the place, even its born position. The aim is to give an idea about the nature of the space free from its location, to be able to get the best from its gifts.

This paper mainly focused on the garden's tempting characteristics from a sensuous point of view and also with regard to its organization. But the main point which was not fully pondered here is the unity, which in fact its nature makes it hard to explain. Experiencing the space closely is the only way to get a clear understanding of its unity.

The focal point in the garden and most of traditional Iranian spaces is the spatial unity shared between all elements; the visitor and the visited. This can be found in poetries and all other artistic works of the people of this land. What we stress on is the sense of harmony and unity which is felt in the visitor strolling in the space. The motives to this unity are not just natural factors but a nature brought to order. People feel a whole new touch of nature by the order which is born by a truth seeking soul. This is a feeling which takes in all human senses - body and soul to come flourishing inside.

As a final say, the Persian garden can be seen as a melodious and pleasant poet which is adorned with the beauty of the nature; displaying a harmo- nious seen in front of the visitor's eyes and taking him up to the greatest excitements he has ever felt.

Going on any track and analyzing the garden from any aspect, this is the Persian garden after all. It should be touched and experienced not described or written. This is a space born and lived in the history. Neither the builders intended to exert and use the disciplines and theories. Nor were scientists there to analyze the facts and regulations for a space. The garden has been made by hands of the people, who got to know the human as he really is, as well as the nature and the garden itself.

\section{References}

1 SM. Beheshti, 2009b. The Sonnet of Iranian/ Persian Garden. Golestan-e Honar. Tehran: Iranian Academic Art. 11, 8-12.

2 M. Khansari, M. Reza Moghtader, \& M.Yavari, 2004. The Persian Garden: Echoes of Paradise. Washington D.C: Mage Publishers.
3 N. Gerlach-Spriggs, RE. Kaufman, \& SB. Warner, Jr. 1998. Restorative Gardens: The Healing Landscape. New Haven: Yale University Press.

4 The World Health Organization Defines Health as "A State of Complete Physical, Mental and Social Well-Being and Not Merely the Absence of Disease or Infirmity." (www.who.int/ aboutwho/en/definition.html).

5 R.S. Ulrich, 1991. Effects of Interior Design on Wellness: Theory and Recent Scientific Research. Journal of health care interior design. 3, 97-109.

6 R. Kaplan \& S. Kaplan. 1989. The Experience of Nature: A Psychological Perspective. Cambridge: Cambridge University Press.

6 S. Kaplan. 1995. The Restorative Benefits of Nature: Towards an Integrative Framework. Journal of Environmental Psychology. 15, 169182.

$7 \quad$ KM. Korpela, T. Hartig, FG. Kaiser, \& U. Fuhrer. 2001. Restorative Experiences and SelfRegulation in Favorite Places. Journal of Environment and Behavior. 33, 572-589.

8 R. Kaplan, S. Kaplan, \& RL. Ryan. 1998. With People in Mind: Design and Management of Everyday Nature. Washington DC: Island Press.

9 SM. Beheshti. 2009a. The World of Persian Garden. Golestan-e Honar. Tehran: Iranian Academic Art. 12, 7-15.

10 MK. Pirniya. 1995. Persian Gardens. Tehran: Abadi. 15, 4-10.

11 DA. Schwartz, E. Ivanich, \& S. Kaplan. 1997. Suppression, Attention and Effort: A Proposed Enhancement for a Promising Theory. Behavioral and Brain Sciences. 20, 36-37.

12 YF. Tuan. 1993. Passing Strange and Wonderful. Washington DC: Island Press.

13 RM. Downs \& D. Stea. 1973. Cognitive Maps and Spatial Behavior: Process and Products. In: RM. Downs \& D. Stea (Eds.), Image and Environment. Aldine Publishing, Chicago. pp. 8-26.

14 R. Rawlings. 1998. Healing Gardens. Minocqua: Willow Creek Press.

15 D. Ackerman. 1990. A Natural History of Senses. New York: Random House.

16 M. Conan. 2004. Essais de poétique des jardins, Florence. Leo S. Italy: Olschki

17 A term stemming from the root-verb meaning etymologically acceptance by tradition- a spiritual concert, a musical ceremony (http://en.wikipedia.org/wiki/Sema)

18 RH. Rabinson. 1992. The Planting Design Handbook. Cambridge: Cambridge University Press.

19 DE. Berlyn. 1960. Conflict, Arousal, and Curiosity. New York: Mc Graw-Hill Book Co.

20 JA. Jakle. 1987. The Visual Elements of Landscape. Massachusetts: The University of Massachusetts press.

21 K. Lynch. 1960. The Image of the City. Cambridge: Technology Press.

22 J. Cox. 1993. Creating a Garden for the Senses. New York: Abbeville Press. 
23 G. Earle. 1966. A Manual of Design Theory for Landscape Architects. SUNY College of Environmental Science and Forestry lecture notes.

24 AJ. Downing. 1921. Landscape Gardening. New York: John Wiley \& Sons Inc.

25 J. Cornell, 1994. Mandala: Luminous Symbols for Healing. Wheaton, IL: Theosophical Pub.
26 C. Alexander. 1979. The Timeless Way of Building. Oxford: Oxford University Press.

27 2004. Contemporary Tehran museum. "Bagh irani, Hekmate kohan manzare jaded" Persian garden: Traditional wisdom, new landscape. Tehran: Contemporary Tehran Museum Press. pp. 201. 